\title{
Benefits and Challenges of Inclusive Schools in Implementing Education for All in Indonesia
}

\author{
Syamsul Bakhri ${ }^{1}$, Alan Sigit Fibrianto ${ }^{1}$ and Inta Rafika Hudi ${ }^{2}$ \\ ${ }^{1}$ Student of Sociological Postgraduate Program, Universitas Sebelas Maret, Surakarta, Indonesia \\ ${ }^{2}$ Postgraduate Program of Social Science Education, Universitas Negeri Yogyakarta, Indonesia \\ s_bakhri@rocketmail.com, alansigitfibrianto53@gmail.com,rafikahudi@gmail.com
}

\begin{abstract}
:
In Indonesia, inclusive education has been applying since 2001, however in its application many constraints were encountered and few disabled children can be enrolled in inclusive school. This descriptive qualitative research with library study approach aimed to find out the benefit and challenge of inclusive school as social capital, economic capital, cultural capital, and symbolic capital of children with special needs in the implementation of education for all. Data validation was carried out using data source triangulation. The data was obtained through integrating those from newspaper, journal and book relevant to the application of inclusive education during 2001-2017, and they were then analyzed using Bourdieu's Habitus theory. The result of research showed that the benefit of Inclusive school is very important to realize the inclusive community, provide more responsive, supporting, and empowering service, to help self-confidence and spirit the disable children, reduce stigma and discrimination by community, confirm the importance of inclusive school through elaboration from parent experience and disabled children point of views. The challenges of inclusive school in realizing education for all, among others, are the difficulty to identify the disabled children's aptitude, no integration between school and therapeutic center for disabled children, limited number of educator for disabled children, limited knowledge of parents in facilitating the growth and development of disabled children and inadequate infrastructures of school.
\end{abstract}

Keywords: Inclusive School, Role, Benefit, Challenge, Education for All

\section{INTRODUCTION}

Education is a basic need for everyone to ensure his life sustainability in order to be more helpful. Thus, government has a duty to give quality educational services to each of its citizen without any exception, including those having any different ability (difabel), as mentioned in Article 31 paragraph 1 of the 1945 Constitution [1].

Up to now, children with different ability (difabel) have been provided with special education facilities adjusted with their disability level and type, called Special School (Sekolah Luar Biasal SLB). Unconsciously, the education system of special school has created an exclusivism wall for the child with special needs. So far, this exclusivism wall has unconsciously inhibited the process of knowing each other between difabel and non-difabel children. As a result, in the social interaction in the society, the difabel group becomes a community alienated from the social dynamics in society. Society becomes unfamiliar with difabel group life. Whereas, difabel group itself feels that their presence is not an integral part of society life around them.

Along with the developing demand of difabel group in expressing their rights, a concept of inclusive education arises. One of International agreements supporting the realization of inclusive education system is Convention on the Rights of person with Disabilities and Optional Protocol, ratified on March 2007. The article 24 of this Convention states that every country has a duty to administer inclusive education system on every education level [2]. Meanwhile, one of its objectives is to support the realization of difabel's full participation in society life. But, in the implementation of inclusive education system in Indonesia, there is a trade-off between the central government, local government, and educational practitioners, in this case the teachers.

Inclusive education is defined as a system of educational service which involves the children with special needs to learn together with their peer in regular school closest to their house [3]. In inclusive education, the school has to accommodate all students regardless their physical, intellectual, social-emotional, linguistic or other conditions.

This inclusive education paradigm is similar with Stainback's view in Tarmansyah (2007) that inclusive school is a school accommodating all students in the same class. Such the school provides a feasible, challenging educational program, but it is adjusted with the ability and need of individual students. Inclusive 
school is also a place for children to be accepted as a part of the class, and to help each other, along with either teachers or their peers or society members in order to fulfill their individual needs. Thus, inclusive school can be a bridge for the children with special needs to be developed and to access education as high as possible [4].

The main obstacle the children with special needs encounter to be developed and to access education as high as possible actually is not his/ her disability, but the society's acceptance. As long as there are appropriate facilities and infrastructures and special handling, they will be able to solve the disability obstacles. Precisely, the matter difficult to solve is social obstacle. Even, according to Choiri and Yusuf (2009), internal obstacles the children with special needs have are generally also caused by negative social perspective on him/ her. For that reason, if inclusive education runs properly, it will ensure that every child will get service to develop his/ her potency. Additionally, children will be accustomed to be tolerant, empathic, and to interact directly between normal students and students with special needs appropriately, and the children with special needs will not be inferior or feel not being accepted in their environment, so that it will create social justice [5].

The application of inclusive school in Indonesia still faces various obstacles, including inadequate supporting facilities for inclusive education system, limited knowledge and skills owned by the teachers of inclusive school, the problem of trade-off between the central government, local government, and educational practitioners, in this case educator. Moreover, the general education curriculum system existing has not accommodated yet the existence of children with different ability (difabel). If it is not anticipated through an appropriate special policy, it will hinder a fair treatment and access for the children with special needs to education, for example, in joining education in the proximate regular school because not all schools have applied inclusive education. In addition, it will also inhibit the successful implementation of inclusive education.

Thus, a research should be conducted studying specifically this problem with sociology approach as inclusive education is closely related to society's social system, perception, social interaction with difabel group, and alienation of difabel group from the social dynamics in the society. Just like what is aforementioned, the most difficult obstacle for the children with special needs is society's social acceptance or social obstacle. The selection of a research on inclusive education problem through educational sociology analysis is expected to give an in-depth understanding on inclusive education viewed from sociological view, become a critique and input to the government in implementing inclusive education in Indonesia. Thus, this research studies the Inclusive school as a Social Capital, Economy Capital,
Cultural capital, and Symbolic Capital in the Implementation of Education for All.

\section{METHODS}

This descriptive qualitative study with literature study approach aimed to find out the benefits and challenges of inclusive school as a social capital, economy capital, cultural capital, and symbolic capital of the children with special needs in the implementation of education for all. Data validity was obtained by combining one data with another. By integrating data from newspapers, journals, and books on the application of inclusive education in Indonesia, they were analyzed later using Bourdieu's Habitus theory. The research process with library study was conducted by identifying and finding some relevant information on the implementation of inclusive school in Indonesia, analyzing using Bourdieu's Habitus theory, and then developing, and expressing it corresponding to the author's ideas. Library research should use subject title, books available in the library, searching for citations and related notes, and making question lists according to keywords [6].

\section{RESULT AND DISCUSSION}

Indonesia towards Inclusive Education has been tried out in some areas since 2001, and formally declared on $11^{\text {th }}$ August 2004 in Bandung. Since 2001, government has started a tryout of pioneering inclusive school in Daerah Istimewa Yogyakarta (Special Region of Yogyakarta) Province with 12 schools in Gunung Kidul area and 35 schools in Daerah Khusus Ibukota Jakarta (Special Region of Jakarta) Province. In 2008, there are 254 inclusive schools in Indonesia from Elementary Schools until Senior High Schools. The Directorate of Special Education has facilitated some provinces and regions to become "an Inclusive Province or Municipal or Regency". In 2013 there were more than 2,100 regular schools declaring to be inclusive schools and 31,734 schools in 2017 in Indonesia. There were 23,196 schools at Elementary School, 5,660 Junior High School, and 2,869 schools in Senior High School levels. From those numbers of schools, there were 159,002 children with special needs served in Inclusive Schools (Directorate of Special Education and Special Service Education) [7]. But, with the increasing number of inclusive schools in Indonesia, the quality of the educational services for the children in Inclusive school was still far from ideal.

The Directorate of Special Education and Special Service Education (2016) said that originally the Children with Special Needs included impairment, handicap, and disability only, so education for the children with special needs is held in a special (special) school, and normal children in regular schools. But, nowadays the category of children with special needs has 
developed in a broader understanding, that is, those blind, deaf, developing speech and language disorder, intellectual disability, physical disability, personality disorder, autism (autistic children), hyperactive (attention deficit disorder with hyperactive), children with learning disability (learning disability or specific learning disability), and multi-handicapped and developmentally disabled children.

In Republic of Indonesia National Education Ministry's Regulation Number 70, 2009, children who become the victims of narcotic, drug and other addictive substance abuses are also categorized into those with special needs. Some children with special talent and/ or intelligence are also categorized into those with special needs [8].

Schools carrying out inclusive education are divided into two types. The first is Regular School/ general school accommodating all children with special needs. The second is special school accommodating normal children. Meanwhile, the alternative of Inclusive Education Service can be done with Full Regular Class; Regular Class with Additional Guidance inside the Class; Regular Class with Additional Guidance outside the Class; Special Class with An Opportunity to Join Regular Class; Full Special School, and Dormitory Special School.

The matter to be noticed by the schools carrying out inclusive education, according to the Directorate of Special Education and Special Service Education (2016), is that the schools should provide a class condition that is warm, friendly in accepting diversity, and appreciating differences. The schools should be ready to manage heterogeneous classes by applying such a curriculum and learning with student centered approach emphasizing on the differences of individual children. Teachers have to apply an interactive learning. They are required to have collaboration with other professions or other resources in planning, implementation, and evaluation. Teachers are required to involve parents significantly in education process.

Nowadays, inclusive education Curriculum uses regular school curriculum (national curriculum) modified (improved) corresponding to the developmental stage of children with special needs, by considering their characteristics and intelligence level. Satrio (2016) suggests that curriculum modification and curriculum development of inclusive education are applied to time allocation; curriculum content/ material, learning process, facilities and infrastructure; learning environment; and class management [9].

Modification/development of inclusive education curriculum can be done by the Curriculum Developer Team, consisting of teachers teaching in inclusive class in cooperation with various related parties, especially special mentor teachers (Special Education teachers) experienced with teaching in Special Schools, and Expert of Special Education (Orthopaedagogy), which are led by the Headmaster of Inclusive Elementary School and have been coordinated by the Education Authorities. Curriculum development is carried out by modifying time allocation, content/ material, and learning process.

In inclusive education, the school has to accommodate all children regardless their physical, intellectual, social-emotional, linguistics condition, or other conditions. Inclusive school, according to Tarmansyah (2007), is the one accommodating all students in the same class.

Karsidi (2009) says that a factor inhibiting inclusive education is the regular schools' declination to idea of inclusive education [10]. In addition, according to Sunardi (2009) dilemma or obstacle of inclusive school implementation in Indonesia lies on the New Student Admission System, especially in Junior and High School education level using National Examination scores as the recruitment criteria [11].

In addition, the presence of challenges to be solved immediately in the implementation of inclusive education in Indonesia is confirmed by the result of Juang Sunanto's study (2009) explained as follows. Originally teachers have a time to feel worried that it will decrease the school's image; There is protest against a situation where a child with special needs is promoted to next grade whereas some normal children are not; There is no special teacher, but it instead becomes a challenge to find a new (creative) method through togetherness, mutual discussion, sharing; The change and the process of learning adaptation are conducted continuously through cooperation, motivating each other, helping each other, supporting each other, communication, and learning from experience; Developing a cooperation among teachers and improving the communication with parents; though it is recognized as increasing additional load, but it is accepted as a challenge; The learning of children with disabilities is done distinctively, by creating a situation enabling all students to learn, and also the implementation of attention and affection approaches [12].

Meanwhile, Wulansari's (2016) study emphasized on the need for considering the work culture concern factor and social values developing in school in the implementation of inclusive education [13].

To fulfill the requirement or acceptance socially, individual should have capital in fulfilling his interaction and social space with others. Capital, according to Bourdieu, consists of economic, social, cultural, and symbolic capital (Ritzer and Goodman, 2012) [14]. Habitus are mental or cognitive structure used by an actor to face social life and imagined as social structure that is internalized and then embodied. In relation to inclusive school, teachers' and schoolmates' habit of mutual empathy, tolerance, and same treatment to students with disabilities and normal students which have been learnt by a student since he/she was young in 
the school environment will be carried away until he/she is adult, because this habit has been internalized into himself. In addition, the form of school rules accepting and treating students with special needs equally to other students should be obeyed, because of the obedience of the members of school and individual formerly a rule can be a habit because it has been internalized into individual. Thus, it can be said that habitus in society will be created because school internalizes them and will become habitus that will be embodied continuously in social life.

Habitus at a certain time is a result of collective creation taking place during a relatively long historical period, so that its internalization process or the result of habituation at inclusive school will not be seen in a short term. According to Beurdeu in Ritzer and Goodman (2003), habitus that produces and are produced by social life will not drive habitus and social life; habitus merely "proposes" something that should be thought by people and something they should choose to do [15].

Bourdieu rejects the social class to be reduced as only economic problem or productive relationship, but it is defined by habitus (Ritzer and Goodman, 2012). Habitus of students who actively ask and answer some questions from teacher or make a discussion (domain) in class has a higher social class than that of passive students who do not ask and answer the teacher's question. It is here that social class is dependent on the habitus, not on the ownership of production. Taste has become the regulator of matches in domain, because the taste of active students is reading scientific books becoming their habitus, whereas the taste of passive students is that they do not like to read books. Thus, why the social class of active student is higher than passive student? It is because his taste is determining the cultural capital (knowledge) and the habitus as well. Taste, capital, habitus, and social class and domain, are dialectics one to another. Here, inclusive schools can give all citizens the same opportunity of getting social status they want in society.

For the students to develop themselves appropriately, the can join school extracurricular activities; it is a relation between domain and capital. Students can enter into extracurricular domain at school corresponding to their talent in order to improve cultural capital (speaking), soft skill and social capital (friendship). It can also maximize domain in virtual world, where school provides electronic learning or accompaniment by using blog, twitter, facebook media for introverted students to express their deepest feeling in order to become more extroverted. In this case, domain influences habitus, and also influences social capital because of their talent, students can be helpful for many people or because of accustomed with writing on blog, and finally they become famous writers.

According to Ritzer and Goodman (2012) there is a distinction in the dialectics of taste, habitus, social class and domain. Distinction is aesthetical preference of a different group in society between artists and intellectual, which is a reflection of never ending struggle between different groups from dominant class to define culture and all social worlds. So that, in inclusive school, it needs a finger print system of children's talent and intellectual to find out the children's learning types and the children's talent, so that it can support the children's process in achieving their ideals corresponding to the taste or the desire of each child.

Bourdieu in Ritzer and Goodman (2012) assumes social reality as a space typology, with various arenas inside it; politics, art, entertainment, academics, religion, philosophy. Arena relates to habitus, capital, social class, and taste, which is used as a tool to dominate the arena. Symbolic violence is used to attack other individual's habitus. Curriculum can belong to symbolic violence, because curriculum is used as a creative border for teachers' learning method the implication of which impacts on the habitus (cognitive) ability of students. Curriculum describes symbolic power of dominant class (government) over the dominated class (teachers) and the most dominated class (students). Therefore, teachers should be are creative, revolutionary and not referring merely to government curriculum method, but educate the students' mentality in order to be more creative (entrepreneur) and revolutionary (agents of social changes) corresponding to their talent. The teachers' task now is not merely to ask the students to work on some tasks, but also to share knowledge and have dialogue leading to a condition of mutual respect in an equality concept.

According to Bourdieu in Fashri (2007), those capitals can be classified into four groups, i.e. economic, cultural, social, and symbolic capitals. In this case, they can become capitals in achieving inclusive society through inclusive school [16].

Regarding, economic capital, inclusive school in analyzing economic capital makes it the positive social changes in society. In the term of cultural capital, inclusive school in the analysis of cultural capital is functioned as local culture defense. Social capital, inclusive school in social capital analysis is functioned as culture reproduction and the former of society's trust to the difabel's ability. Symbolic capital, inclusive school in symbolic capital analysis is functioned as social transformation.

From the above explanation, the execution of inclusive education globally and evenly in Indonesia based on the cultural identity (local culture) entrepreneurship, and children's talent is a solution given by the researcher in order to be a habitus in education world and Indonesia society. Thus, it will create habitus of inclusive society giving justice for the children with special needs to get education and rights in community. The executed mandate of The 1945 Constitution (UUD 1945) Article 31 paragraph 1, Act Number 8 Article 10 
and 40 of 2016 about education for disabilities, and the realization of social justice for all people of Indonesia, corresponding to the fifth principle of Pancasila, the national principle of Indonesia.

The Spiritual Foundation of why inclusive education should be implemented throughout Indonesia has been explained in Al-Quran Surah An Nisa (9) (the Republic of Indonesia's Religion Ministry: 2005) “And let those (executors and guardians) have the same fear in their minds as they would have for their own, if they had left leak offspring behind. So let them fear Allah and speak right words". In addition, it is also Surah Az Zuhruf (32) "Do they distribute the mercy of your Lord? It is We who have apportioned among them their livelihood in the life of this world and have raised some of them above others in degrees [of rank] that they may make use of one another for service. But the mercy of your Lord is better than whatever they accumulate" [17].

The legal foundation of why inclusive education should be implemented throughout Indonesia includes United Nation Convention on Children's rights on year 1989; Education Declaration for All in Thailand on 1990; Salamanka Agreement on Inclusive Education 1994; the 1945 Constitution (UUD 1945) Article 31 explained in National Education System Regulation Number 20 of 2003 on the giving of other color in providing education for disable children; SE Dirjen Dikdasmen Depdiknas Number 380/C.C6/MN/2003 on $20^{\text {th }}$ January 2003 on the Stub of Implementation of Integrated Education; Declaration of Bandung on Towards Inclusive Education on 2004; the Regulation of National Ministry of Education Number 70 of 2009 on Inclusive Education; Act Number 35 of 2014 on Child Protection; Government Regulation Number 12 of 2015 on the National Education Standard; Act Number 8 of 2016 on Disabilities.

The comprehensive and even implementation does not mean that all schools should become inclusive schools, but the nationally standardized school, educators, facilities and infrastructures, inclusive school curriculum by considering the number of children with special needs in those area, is more important thing because it will restore parents' trust and society's (mental and cognitive structure) that inclusive education is an education which has feasible process, feasible facilities, giving chance of success, hope to achieve the ideal and produce graduates who have high achievement, capable to continue their study into college, and being independent. Therefore, in its application, it needs some points to do.

Firstly, there should be a process of making the parents aware of not being shy, not just letting the children with special needs go, handling the children with special needs and the importance of education to children with special needs in order to be independent in the future. It needs the presence of counselor team and the formation of parents-children with special needs community in order to be capable to exchange experience, handling, and spirit of educating, bringing up children with special needs (Indonesian Difabel's Parents Movement).

Secondly, the availability of therapist center should be standardized nationally. Thus, the parents of children with special needs can consult with psychologists and therapists to handle and to give the best therapy for the development of children with special needs. Nowadays, autism can be healed if the child gets an appropriate therapy. In addition, children with other special needs, if they get an appropriate therapy will also help to give a better growth and development process. Then, do finger print test as early as possible to find out child's talent and child's type of learning (is it visual, audiovisual, or kinesthetic), so that it will help teachers and parents in giving an appropriate learning, joining an appropriate extracurricular corresponding to their talent, and can develop their potential and talent as early as possible. Therefore, it needs a national standardized center of therapists in each municipal or regency in Indonesia.

Thirdly, inclusive school should be standardized nationally, on its curriculum; facilities and infrastructures, feasible educational process, and can produce children with high achievement, can continue to college, and become independent. It is not a must that all schools become inclusive, but the quality on national standardized inclusive school should be corresponding to the needs of each region. Therefore, it needs inclusive school (For example the Elementary School on each village or at least sub-district, Junior High School on each sub-district, and Senior High School on each municipal or regency). The number of school is determined by considering the data of children with special needs in each region. For the accessibility, government gives school car or bus facilities for the children with special needs.

Inclusive school or the implementation of inclusive education globally and evenly in Indonesia does not mean that every difabel or child with special needs will study at regular school, but it is only children who do not have cognitive problems, who can study at regular school. For the children with cognitive problems, the researcher gives solution, by giving a therapy which is suitable with their needs, developing their talent (from the result of finger print test), getting Equality School (Kejar Paket A, B, C), Alternative School (Inclusionbased Home Schooling and Natural School) or Special School, with accompaniment of tutors or talent private teacher and their parents, joining work training or work skilling (sewing, laundry, screen printing, batik, painting, etc.) in order that in the future they can work or become entrepreneurs (independent), and in addition, children should gain difabel electronic access which is called by the writer with electronic Punakawan to give information access of therapists center, online consultation, e-learning, problem complaints, 
information of inclusive school, and difabel accessibility in accessing public facilities, for example library (For example audio book for the blind). The electronic Punakawan is made and managed by the government and regional government, which is free to be downloaded by all Indonesian citizens. If a child with special needs does not capable to buy a smartphone, the government is able to give some help for him by previously doing data collection and giving training to the parents and the child with special needs on its uses.

It means that in theory analysis of Bourdeu in forming habitus of inclusive society, School or education does not mean inside a class which is covered by a square wall, but it can be done everywhere. Indonesia is rich of natural resources, cultures, and its local wisdom is the best class for all children of nation. It definitely needs a careful preparation at first, before implementing inclusive education evenly and thoroughly in Indonesia by preparing some important things.

Firstly, The implementation of Act Number 8 of 2016 on Person with Disability, Article 10 paragraph (a)Every person with disability has rights to get a quality education on every sector, major, type, and grade of education inclusively and specifically. Article 40 paragraph 3, Government and Local Government has to involve child with disability in 12 years compulsory education program. Government prepares and arranges the implementation of inclusive education thoroughly, which means that every school nearest to a person with disability has to accept the child in the school if he does not have any problems [18].

Secondly, The formation of inclusive national curriculum system is based on cultural identity. The center of examination and therapy for children with special needs is built in each municipal and regency throughout Indonesia. This therapy center must be free for children with special needs, whose parents are economically incapable. It is important because basically, in such a condition children with special needs should get a therapy and teachers will experience some difficulties if the children with special needs in a certain condition, such as severe or moderate autism. Minimum in mild autism condition, the learners can accept the lesson well and interact appropriately.

Thirdly, The giving of training to the teachers and headmaster thoroughly in order to be capable in implementing inclusive education and opening civil servants recruitment to fill the teachers formation who hold special education bachelor as the additional teachers and bachelor of psychology as the analyst of the students' development and consultation room for students and their parents.

Fourthly, a regulation should be implemented for all state universities to give material and training to all their education students about the way of handling and learning of children with special needs.
Fifthly, Implementing a massive socialization to all layers of society about the importance of inclusive education and students can join formal school education without any exception if the children are stated capable for joining regular education by a therapist or psychologist.

Sixthly, Doing an internalization of inclusive society values in the inclusive school lessons and the school should look for a solution at a certain lesson, for example an assessment of $100 \mathrm{M}$ run on Exercise Lesson, if the child uses wheel chair, it can be changed with written examination or other assessment which can be done by the child.

Seventhly, Inclusive school is integrated with home learning (private teacher/ parents) for children with special needs who have below average IQ, which is adjusted to the extra hours in the curriculum adjustment of material achievements, therapies for the children with special needs, place for lesson course or talent and school extracurricular to support the students' talent.

Eighthly, The integrated of policy, teachers preparation, and implementation of inclusive school by giving training, socialization, and learning to all teachers about the handling to children with special needs and the way to create a cooperative learning atmosphere.

Ninthly, The administration of finger print test to find out the children's talent and type of learning, whether visual, audio visual, or kinesthetic, so it will help teachers in the learning process and the coaching of children's talent.

Tenthly, The System of New Learners Recruitment gives quota for the children with special needs, especially in Secondary and Upper Education that uses National Examination Marks as the criteria of admission.

The Last, The making of Difabel Electronic Application which the researcher calls Punakawan Electronic to give information access to the center of therapist, online consultation, problems complaint, information about inclusive school, difabel accessibility in accessing public facilities such as Legal Aid or library (For example audio book for the blind), and integrated with e-learning as the center of student's learning, students' assignment, and students' assessment, so school, teachers and parents can together monitor and cooperate in the accompaniment to the learners' development.

\section{CONCLUSION}

In order to implement education for all, inclusive school should be implemented throughout Indonesia. The challenges for inclusive schools in Indonesia are in arranging curriculum for inclusive education, completing facilities and infrastructures of inclusive schools, teachers should be able to handle children with special needs, government and parents should give an 
understanding to the society about inclusive education. The benefits of inclusive school are: it will become a fair domain/ arena for all children, the students will learn to respect each other in an equality concept, all children either children with special needs or not, can achieve their ideals corresponding to their talent and will get the same social, cultural, economic, and symbolic capital either from school or society in the future.

\section{REFERENCES}

[1] Undang Undang Dasar Republik Indonesia 1945.

[2] Convention on the Rights of Person with Disabilities and Optional Protocol. yang disahkan pada Maret 2007 pasal 24.

[3] Ilahi, M.T. 2013. Pendidikan Inklusif: Konsep dan Aplikasi. Ar-Ruzz Media: Jogjakarta.

[4] Tarmansyah. 2007. Inklusi Pendidikan untuk Semua. Jakarta: Departemen Pendidikan Nasional Direktorat Jenderal Pendidikan Tinggi Direktorat Ketenagaan.

[5] Choiri, A.S, dan Yusuf, M. 2009. Pendidikan Anak Berkebutuhan Khusus Secara Inklusif. Surakarta: Yuma Pustaka.

[6] Mann, T. 2005. The Oxford Guide to Library Research. 3ed. New York, United States: Oxford University Press Inc.

[7] Direktorat Pendidikan Khusus dan Pendidikan Layanan Khusus. 2016. Online http://pklkdikdas.net/tentang-pklk/pendidikan-inklusif [accessed 26/05/2016].

[8] Peraturan Menteri Pendidikan Nasional Republik Indonesia Nomor 70 Tahun 2009.

[9] Satrio.2016. Inklusi Pendidikan Terhadap Anak Berkebutuhan Khusus.Online http://sekolahmandiri.sch.id/node/18 [accessed 20/05/2016].

[10] Karsidi, R. 2015. Education Development Strategies In Indonesia.UNS Press: Surakarta.

[11] Sunardi (2009). Issues and Problems on Implementation of Inclusive Education for Disable Children In Indonesia. Tsukuba: CRICED University of Tsukuba.

[12] Sunanto, J.2009. Implementasi pendidikan inklusif di Sekolah Dasar. Bandung: Pusat Kajian dan Inovasi Pendidikan Pascasarjana UPI.

[13] Wulansari, A. 2016. Pengaruh Penandaan (Signifikasi), Penguasaan Sumber Daya (Dominasi), Dan Legitimasi Pendidikan Inklusi Terhadap Inklusivitas Pendidikan Sekolah Dasar Di Kota Surakarta Dalam Perspektif Guru. (TESIS: Program Studi Sosiologi Program Pascasarjana Universitas Sebelas Maret Surakarta).

[14] Ritzer, G dan Goodman, D. (Trans: Nurhadi) 2012. Teori Sosiologi Klasik Post Modern Edisi Terbaru.Yogyakarta: Kreasi Wacana.

[15] Ritzer, G dan Goodman, D. 2003.Teori Sosiologi Modern.Jakarta: Kencana.
[16] Fashri, F. 2007. Penyingkapan Kuasa Simbol: Apropriasi Reflektif Pemikiran Pierre Bourdieu.Yogyakarta: Juxtapose.

[17] Departemen Agama RI. 2005. Al-Qur'an dan Terjemahannya. Jakarta: PT.Syamil.

[18] Undang Undang Republik Indonesia Nomor 8 tahun 2016 Penyandang Disabilitas. 15 April 2016. Jakarta: Lembaran Negera Republik Indonesia Tahun 2016 Nomor 69. 